\title{
Nise Dew Disease Reports \\ First report of Tomato chlorotic dwarf viroid (TCDVd) in tomato in Norway and subsequent eradication.
}

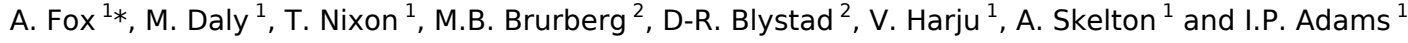 \\ ${ }^{1}$ The Food and Environment Research Agency, Sand Hutton, York, YO41 1LZ, UK; ${ }^{2}$ Bioforsk - Norwegian Institute for \\ Agricultural and Environmental Research, Høgskoleveien 7, 1432, Ås, Norway
}

*E-mail: adrian.fox@fera.gsi.gov.uk

Received: 16 Oct 2012. Published: 19 Feb 2013.

\begin{abstract}
In January 2012 a sample of tomato (Solanum lycopersicon cv Juanita) was submitted to the Food and Environment Research Agency (Fera), via a horticultural consultant, from an established crop in the county Rogaland in Southwest Norway. The sample, from an illuminated crop grown under high light intensity, was sent in following the appearance of an unknown disease, which was spreading through the crop. Symptoms included small and narrow leaves, yellowing and bronzing and a stunted, bushy growth (Figs. 1, 2). The sample was analysed using real-time PCR $\left(\right.$ TaqMan $\left.^{\circledR}\right)$ with primers and probe designed to detect Potato spindle tuber viroid (PSTVd) (Boonham, 2004). Validation of this assay has shown reliable detection also of Tomato chlorotic dwarf viroid (TCDVd). The sample tested positive and the result was confirmed by conventional RT-PCR using primers to detect a broad range of pospiviroids (Verhoeven et al., 2004). A product of the expected size (197 bp) was obtained and confirmed to be TCDVd by nucleotide sequence comparison (GenBank Accession No. JQ975098). Following notification to the Norwegian Food Safety Authority, the finding was confirmed in a new sample that tested positive using the conventional RT-PCR method (Verhoeven et al.,2004), at Bioforsk. The disease spread from three to four plants in December 2011 to several hundred by the end of January 2012. In February and March visual symptoms were detected in all parts of the infected greenhouse. All tomato plants were eradicated and the whole site was disinfected and left empty for eight weeks.
\end{abstract}

A range of TCDVd sequences were obtained from GenBank, and from samples of TCDVd received by Fera from infected petunias found in the UK and the Netherlands during 2010. The sequences of the Fera samples were all identical to the Norwegian isolate (JQ975098). Intraspecific variation (K2P distance) for all TCDVd sequences obtained from GenBank and Fera was 0.021 . The outbreak TCDVd sequence shows $84 \%$ and $100 \%$ identity to PSTVd and TCDVd type-isolates respectively. A neighbour-joining tree showing the relationship of the outbreak TCDVd sequences to other TCDVd and PSTVd sequences (Fig. 3) suggests that the infections in the Norwegian samples may be related to samples obtained during the 2010 European-wide outbreak of TCDVd in Petunias. There is a previous report of an interception of TCDVd on petunia from Finland (EPPO, 2009) but to our knowledge this is the first finding of TCDVd in Norway and as the first outbreak of a pospiviroid infecting tomato in the Nordic region represents the northern-most outbreak of TCDVd in Europe.

\section{Acknowledgements}

The authors would like to thank Erling Fløistad and Dag-Ragnar Blystad, Bioforsk Norway, for the provision of photographs from the outbreak site.

\section{References}

Boonham N, Gonzalez Perez L, Mendez MS, Peralta EL, Blockley A, Walsh K, Barker I, Mumford RA, 2004. Development of a Real-Time RT-PCR assay for the detection of Potato spindle tuber viroid. Journal of Virological Methods, , 139-146.

[http://dx.doi.org/10.1016/j.jviromet.2003.11.005]

EPPO/OEPP (2009) First report of Tomato chlorotic dwarf viroid in Finland. EPPO Reporting Service, 2009/135

[http://archives.eppo.int/EPPOReporting/2009/Rse-0907.pdf].

Verhoeven JThJ, Jansen CCC, Willemen TM, Kox LFF, Owens RA, Roenhorst JW, 2004. Natural infections of tomato by Citrus exocortis viroid, Columnea latent viroid, Potato spindle tuber viroid and Tomato chlorotic dwarf viroid. European Journal of Plant Pathology 110, 823-831. [http://dx.doi.org/10.1007/s10658-004-2493-5]

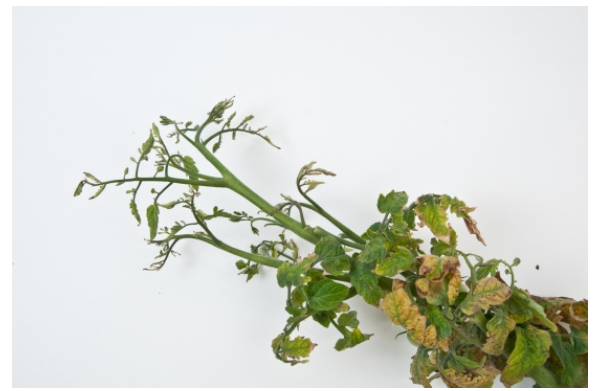

Figure 1

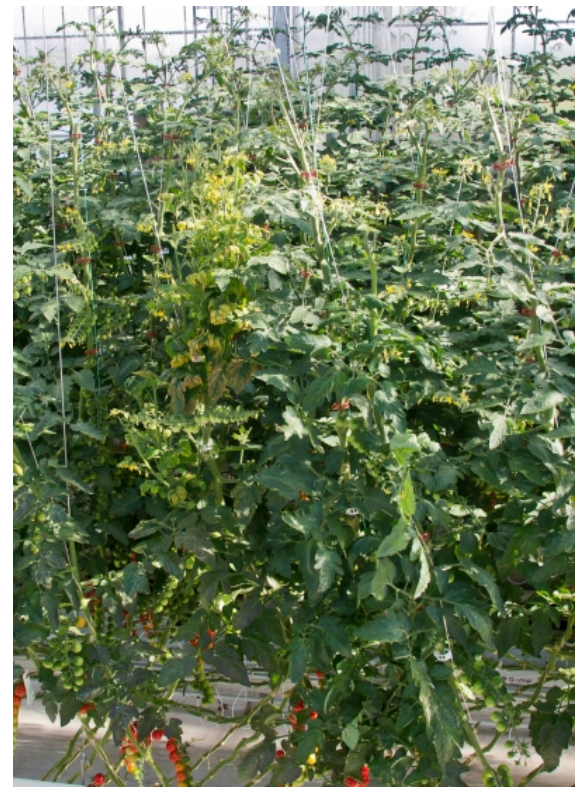

Figure 2

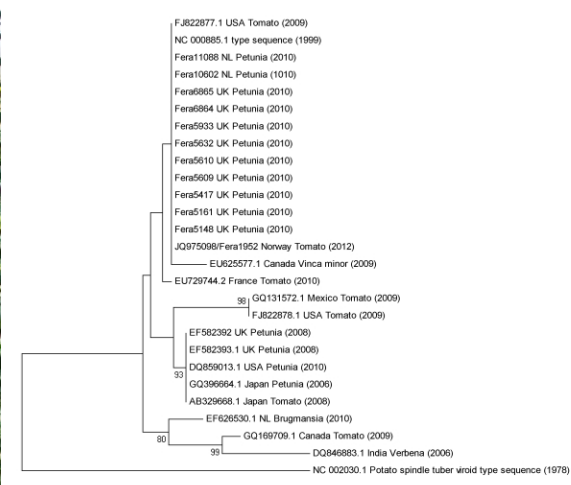

Figure 3

To cite this report: Fox A, Daly M, Nixon T, Brurberg MB, Blystad D, Harju V, Skelton A, Adams IP, 2013. First report of Tomato chlorotic dwarf viroid (TCDVd) in tomato in Norway and subsequent eradication.. New Disease Reports 27, 8.

[http://dx.doi.org/10.5197/j.2044-0588.2013.027.008]

(C) 2013 The Authors

This report was published on-line at www.ndrs.org.uk where high quality versions of the figures can be found.

New Disease Reports is a peer-reviewed on-line journal published by the British Society for Plant Pathology,

for more information visit http://www.ndrs.org.uk/ 